\title{
CD24 and CK4 are upregulated by SIM2, and are predictive biomarkers for chemoradiotherapy and surgery in esophageal cancer
}

\author{
KENJI TAKASHIMA ${ }^{1}$, SATOSHI FUJII ${ }^{2}$, RIE KOMATSUZAKI ${ }^{3}$, MASAYUKI KOMATSU ${ }^{3}$, \\ MARI TAKAHASHI ${ }^{1}$, TAKASHI KOJIMA ${ }^{4}$, HIROYUKI DAIKO ${ }^{5}$, KEIKO MINASHI $^{6}$, \\ FUMIKO CHIWAKI $^{3}$, MANABU MUTO $^{7}$, HIROKI SASAKI $^{3}$ and TOMONORI YANO ${ }^{1}$ \\ ${ }^{1}$ Department of Gastroenterology and Endoscopy, National Cancer Center Hospital East; \\ ${ }^{2}$ Department of Pathology, Exploratory Oncology Research and Clinical Trial Center, Kashiwa, Chiba 277-8577; \\ ${ }^{3}$ Department of Translational Oncology, National Cancer Center Research Institute, Tokyo 104-0045; \\ Departments of ${ }^{4}$ Gastrointestinal Oncology and ${ }^{5}$ Esophageal Surgery, National Cancer Center Hospital East, \\ Kashiwa, Chiba 277-8577; ${ }^{6}$ Department of Clinical Trial Promotion, Chiba Cancer Center, Chiba 260-8717; \\ ${ }^{7}$ Department of Therapeutic Oncology, Kyoto University Graduate School of Medicine, Kyoto 606-8507, Japan
}

Received May 23, 2019; Accepted November 19, 2019

DOI: $10.3892 / \mathrm{ijo} .2020 .4963$

\begin{abstract}
Definitive chemoradiotherapy (CRT) is a less invasive therapy compared with surgery for some types of cancer; however, the 5-year survival rate of patients with stages II-III esophageal squamous cell carcinoma (ESCC) is only $37 \%$. Therefore, prediction of CRT responders is necessary. Unfortunately, no definitive biomarker exists that is useful to predict survival outcome following CRT. From our previous microarray study, $C D 24$ and keratin 4 (KRT4), which encodes cytokeratin 4 (CK4), were overexpressed in the favorable prognostic epithelial subtype with SIM bHLH transcription factor 2 (SIM2) expression. This study investigated the association between their mRNA and protein expression levels, and clinicopathological characteristics, and also investigated the functions of CD24 in SIM2-mediated tumor differentiation and CRT sensitivity. High CD24 and KRT4 mRNA expression was associated with a favorable prognosis following CRT. Multivariate analyses revealed that high CD24 and CK4 protein expression, as determined by immunohistochemistry, and differentiated type were independent factors for predicting
\end{abstract}

Correspondence to: Dr Hiroki Sasaki, Department of Translational Oncology, National Cancer Center Research Institute, 1-1 Tsukiji 5-Chome, Chuo-ku, Tokyo 104-0045, Japan

E-mail: hksasaki@ncc.go.jp

Dr Tomonori Yano, Department of Gastroenterology and Endoscopy, National Cancer Center Hospital East, 6-5-1 Kashiwanoha, Kashiwa, Chiba 277-8577, Japan

E-mail: toyano@ncc.go.jp

Key words: esophageal squamous cell carcinoma, SIM bHLH transcription factor 2, CD24, keratin 4, chemoradiotherapy a favorable prognosis in response to CRT. Notably, in cases with low CD24 or CK4, surgery was suggested to be a good therapeutic modality compared with CRT. CD24 and KRT4 were expressed preferentially in differentiated layers of the normal esophageal mucosa, and their mRNA expression in 3D cultured ESCC cells was induced by SIM2 transfection, thus suggesting that $C D 24$ and $K R T 4$ were downstream differentiation markers of SIM2. Furthermore, CD24 small interfering RNA increased the mRNA expression levels of superoxide dismutase 2 and enhanced $\mathrm{H}_{2} \mathrm{O}_{2}$ resistance, thus indicating the involvement of $\mathrm{CD} 24$ in the radiosensitivity of patients with ESCC; however, it had no effect on cisplatin sensitivity. In conclusion, the two markers CD24 and CK4 may be considered predictive biomarkers for definitive CRT.

\section{Introduction}

Esophageal cancer is the sixth most common cause of cancer-associated mortality worldwide (1). Neoadjuvant chemoradiotherapy (CRT) followed by esophagectomy is the standard treatment for locally advanced esophageal squamous cell carcinoma (ESCC) in Western countries, whereas neoadjuvant chemotherapy (CT) followed by esophagectomy or definitive CRT (CRT alone as a primary therapy) are the standard treatments in Japan (2). Although neoadjuvant CT and definitive CRT improve the prognosis of patients with ESCC, the 5-year survival rate is still $37-55 \%$ (2,3). Local recurrence and metastasis are major causes of poor prognosis. Nevertheless, the prediction is difficult, creating a need for predictive factors that select patients who are potentially curable with definitive CRT.

By comparing microarray profiles among pre- and post-treatment biopsy specimens of patients with ESCC, our previous study identified a good responder subtype with cytotoxic T-lymphocyte signatures that were activated by 
CRT (4). Clustering analysis of 234 tumor immunity-related genes in 121 pre-treatment ESCC specimens distinguished the immune-activated cases, termed I-type, from other cases. In the I-type, the clinical outcome of cadherin 2 $(\mathrm{CDH} 2)$-negative cases was significantly better than that of the CDH2-positive cases. Notably, CD24, keratin 4 (KRT4) and SIM bHLH transcription factor 2 (SIM2) were overexpressed in the CDH2-negative cases (4). The differentiation degree in squamous cell carcinoma has been reported to influence sensitivity and prognosis in response to CRT $(5,6)$. SIM2 is a member of the basic HLH-PER-ARNT-SIM transcription factors, which is isolated from a Down's syndrome-crucial region (7-9). Aberrant SIM2 expression has been reported in several types of cancer $(10,11)$. Recently, we identified SIM2 as a predictive biomarker for patients with cervical cancer who were potentially curable with CRT (12). Furthermore, our previous study reported that SIM2 in ESCC might be a key transcription factor involved in tumor differentiation and CRT sensitivity through downregulation of DNA repair and antioxidant genes. Therefore, SIM2 may be associated with the response to definitive CRT (13).

CD24 is a small mucin-like cell surface protein, which is expressed on lymphocytes and epithelial cells (14), and is also expressed in various types of cancer, including colorectal, pancreatic, lung, liver, ovarian and breast cancer (15-18). These studies also reported that CD24 overexpression is associated with an aggressive course of the disease. Furthermore, CD24 may serve a role in the metastasis of breast cancer (19-21), cervical cancer (18), gastric cancer (22) and bladder cancer $(23,24)$. CD24 has also been reported as a marker for stem cells in pancreatic and ovarian cancer $(25,26)$. However, the role of CD24 in ESCC remains obscure.

KRT4 encodes a type II cytokeratin, cytokeratin 4 (CK4), which is specifically found in differentiated layers of the esophageal epithelia. KRT4 is downregulated in ESCC and head and neck squamous cell carcinoma compared with in normal squamous epithelium $(27,28)$. Its low expression is associated with local recurrence of head and neck squamous cell carcinoma (29). However, the biological functions and clinical significance of CK4 and CD24 remain unknown in ESCC. This study investigated the association between their mRNA and protein expression levels, and clinicopathological characteristics, and also investigated the functions of CD24 in SIM2-mediated tumor differentiation and CRT sensitivity.

\section{Materials and methods}

Clinical samples. Patients with ESCC who received definitive CRT or curative esophagectomy with extended lymph node dissection (surgery) as an initial treatment at the National Cancer Center Hospital East (Kashiwa, Japan) between June 2005 and March 2009 were recruited. The eligibility criteria were as follows: i) Patients pathologically diagnosed, using biopsy specimens, with squamous cell carcinoma prior to receiving definitive CRT or surgery; ii) patients with stage II/III ESCC who underwent definitive CRT or surgery; and iii) patients $<75$ years old whose performance status according to the Eastern Cooperative Oncology Group was 0.1 (30). Clinical staging before neoadjuvant CT (in the surgery group) or definitive CRT was determined according to the Union for
International Cancer Control-Tumor-Node-Metastasis classification (6th edition) (31), based on endoscopic findings and contrast enhanced computed tomography (CECT). Patients with prior or concurrent types of cancer were excluded from this study. In the surgery group, clinical outcomes were determined following surgery alone or neoadjuvant CT followed by surgery. However, patients who were not able to receive a scheduled complete course of definitive CRT were included, because such patients whose therapeutic responses are unpredictable could not be excluded prior to treatment.

Cell culture. The ESCC T.Tn cell line was purchased from the Japanese Collection of Research Bioresources Cell Bank. T.Tn cells were propagated in DMEM/Ham's F-12 (Wako Pure Chemical Industries, Ltd.) supplemented with $10 \%$ fetal bovine serum (Gibco; Thermo Fisher Scientific, Inc.) and $1 \%$ penicillin-streptomycin (Gibco; Thermo Fisher Scientific, Inc.), and maintained at $37^{\circ} \mathrm{C}$ in $95 \%$ humidified air containing $5 \% \mathrm{CO}_{2}$. A 35-mm NanoCulture Plate (SCIVAX Corporation) was used for three-dimensional (3D) culture (13).

Laser-captured micro-dissection (LCM). The human esophagus samples were embedded in TissueTek O.C.T. Compound (Sakura Finetek Japan) and snap-frozen. The cryostat sections $(8 \mu \mathrm{m})$ were dissected using a PixCell II LCM system (Arcturus Engineering, Inc.). To avoid contamination with dysplastic or cancerous tissues, normal esophageal mucosa was obtained from gastric cancer samples with normal esophageal tissue for semi-quantitative reverse transcription-PCR (RT-PCR) analysis of the three cell layers (differentiated, parabasal and basal cell layers).

Microarray analysis. RNA was isolated from the biopsy samples from patients prior to treatment using ISOGEN lysis buffer (Nippon Gene Co., Ltd.), and were biotin-labeled followed by hybridization to microarrays (Human Genome U133 Plus 2.0 Array; Affymetrix, Inc.), according to manufacturer's protocol. The scanned data of the arrays were processed by Affymetrix Microarray Suite version 5.0 (Affymetrix, Inc.). All of the microarray data were deposited in a minimum information about a microarray experiment-compliant database, Gene Expression Omnibus (https://www.ncbi.nlm.nih. gov/geo/); the accession number is GSE69925 (4).

$R T-P C R$. Total RNA was isolated from cells using ISOGEN lysis buffer (Nippon Gene Co., Ltd.) followed by precipitation with isopropanol. RT was performed using oligo dT primers from the SuperScript III First-Stand Synthesis system (Thermo Fisher Scientific, Inc.), according to the manufacturer's protocol. PCR was carried out using the AccuPrimeTaq DNA Polymerase system (Thermo Fisher Scientific, Inc.), within the linear range of amplification, for long isoforms of SIM2 (24 cycles), CD24 (23 cycles) KRT4 (18 cycles) and $\beta$-actin (ACTB; 22 cycles). The thermocycling conditions were as follows: Initial denaturation at $95^{\circ} \mathrm{C}$ for $5 \mathrm{~min}$, followed by the aforementioned number of cycles at $95^{\circ} \mathrm{C}$ for $1 \mathrm{~min}, 56^{\circ} \mathrm{C}$ for $1 \mathrm{~min}$ and $72^{\circ} \mathrm{C}$ for $1 \mathrm{~min}$, with a final extension step at $72^{\circ} \mathrm{C}$ for $10 \mathrm{~min}$. PCR products were then separated by electrophoresis with $2 \%$ agarose gels and results were visualized using ethidium bromide (Wako Pure Chemical Industries, Ltd.). 
RT-quantitative PCR (RT-qPCR) was carried out for long isoforms of $S I M 2, C D H 2$, vimentin (VIM), snail family transcriptional repressor 2 (SNAI2), twist family bHLH transcription factor (TWIST)1, TWIST2, CD24, KRT4 and $A C T B$. In accordance with the manufacturer's protocol, RT was conducted using the SuperScript III First-Stand Synthesis system (Thermo Fisher Scientific, Rockford, IL) and qPCR was performed on a Bio-Rad iCycler with iQ SYBR Green Supermix (Bio-Rad Laboratories, Inc.). The thermocycling conditions were as follows: Initial denaturation at $95^{\circ} \mathrm{C}$ for $2 \mathrm{~min}$, followed by 40 cycles at $95^{\circ} \mathrm{C}$ for $15 \mathrm{sec}$ and $55^{\circ} \mathrm{C}$ for $30 \mathrm{sec}$, and a final step at $95^{\circ} \mathrm{C}$ for $1 \mathrm{~min}$ and $55^{\circ} \mathrm{C}$ for $1 \mathrm{~min}$. Results are presented as linearized quantification cycle $(\mathrm{Cq})$ values normalized to $A C T B$ and the indicated reference value $\left(2^{-\Delta \Delta \mathrm{Cq}}\right)$ (32). Primer sequences are listed in Table I.

Plasmid transfection. The pCMV6-AC-GFP plasmid containing SIM2 cDNA was purchased from OriGene Technologies, Inc. T.Tn cells were plated at $2 \times 10^{6}$ per $10-\mathrm{cm}$ dish, and transfected with either pCMV6-AC-GFP-SIM2 or empty pCMV6-neo (OriGene Technologies, Inc.). Briefly, cells were transfected with $4 \mu \mathrm{g}$ plasmid DNA in $10 \mu \mathrm{l}$ Lipofectamine ${ }^{\circledR} 2000$ (Invitrogen; Thermo Fisher Scientific, Inc.), according to the manufacturer's protocol, overnight at $37^{\circ} \mathrm{C}$. Subsequently, the cells were plated at $6 \times 10^{5}$ cells $/ 3.5 \mathrm{~cm}$ NanoCulture Plate (SCIVAX Corporation).

Immunohistochemistry (IHC) and hematoxylin and eosin (HE) staining. Specimens fixed in $10 \%$ formalin at room temperature for 8-24 h and embedded in paraffin were cut into $4-\mu \mathrm{m}$ sections, which were dewaxed and dehydrated for routine $\mathrm{HE}$ staining.

For IHC, the endogenous peroxidase activity of $4-\mu \mathrm{m}$ sections were cut from paraffin-embedded specimens, and the endogenous peroxidase activity of the sections was blocked with $3 \% \mathrm{H}_{2} \mathrm{O}_{2}$ in ethanol for $5 \mathrm{~min}$ at room temperature, followed by additional blocking with $3 \%$ BSA-PBS (Roche Diagnostics $\mathrm{GmbH}$ ) for $1 \mathrm{~h}$ at room temperature. Antigen retrieval was performed in a microwave oven at $95^{\circ} \mathrm{C}$ using $10 \mathrm{mM}$ citrate buffer (pH 6.0) for 20 min (CD24 antigen) or Target Retrieval Solution (cat. no. S2367; Dako; Agilent Technologies, Inc.; $\mathrm{pH}$ 9.0) for $10 \mathrm{~min}$ (CK4 antigen). Anti-CD24 (1:500; cat. no. NB100-64861; Novus Biologicals, LLC) and anti-CK4 antibodies (1:500; cat. no. ab9004; Abcam) were diluted at 1:500 and slides were incubated with them at $4^{\circ} \mathrm{C}$ overnight. The slides were then incubated with a horseradish peroxidase (HRP)-labeled secondary antibody (Envision ${ }^{\mathrm{TM}} \mathrm{Kit} / \mathrm{HRP}$ system; cat. No. K4063; Dako; Agilent Technologies, Inc.) at room temperature for $30 \mathrm{~min}$ and visualized by DAB (DAB+ Liquid; Dako; Agilent Technologies, Inc.). The positive percentage of cancer cells for each case was determined by a pathologist who was blinded to the clinical data. IHC and HE staining were detected under a Nikon ECLIPSE light microscope (Nikon Corporation) and was analyzed using NIS-Elements BR version 4.10 software (Nikon Corporation).

Small interfering RNA (siRNA) transfection. CD24 siRNAs and control siRNA (cat. no. AM4635) were purchased from Ambion; Thermo Fisher Scientific, Inc. The sequences were as follows: siRNA s2615, UCAAGUAACUCCUCCCAGAtt;
siRNA s2616, CCAGAGUACUUCCAACUCUtt). siRNAs (75 $\mathrm{nM})$ were introduced into $4 \times 10^{5}$ T.Tn cells $(50 \%$ cell confluence) using DharmaFECT 1 Transfection Reagents (GE Healthcare Dharmacon, Inc.) and cells were incubated for 3 days at $37^{\circ} \mathrm{C}$.

Western blotting. Cells were lysed in Laemmli Sample buffer (Bio-Rad Laboratories, Inc.) containing DTT and 1\% protease inhibitor cocktail (Sigma-Aldrich; Merck KGaA), and protein concentration was analyzed using the Protein Quantification Assay (MACHEREY-NAGEL GMBH \& Co. $\mathrm{KG})$. Protein samples $(35 \mu \mathrm{g})$ were separated by electrophoresis using a NovexWedge Well 4-20\% Tris-Glycine Gel (Thermo Fisher Scientific, Inc.). Proteins were transferred to nitrocellulose membranes, which were blocked with 5\% Membrane Blocking Reagent (cat. no. RPN2125; GE Healthcare) for $1 \mathrm{~h}$ at room temperature, and incubated with anti-CD24 (1:200; cat. no. sc-58999; Santa Cruz Biotechnology, Inc.) at $4^{\circ} \mathrm{C}$ overnight or with anti- $\beta$-actin $(1: 3,000$; cat. no. 4967; Cell Signaling Technology, Inc.) at room temperature for $2 \mathrm{~h}$. The membranes were then washed and incubated with HRP-conjugated anti-mouse immunoglobulin (1:3,000; cat. no. P0260; Dako; Agilent Technologies, Inc.) or HRP-conjugated anti-rabbit immunoglobulin (1:3,000; cat. no. P0399; Dako; Agilent Technologies, Inc.) at room temperature for $2 \mathrm{~h}$. Bands were visualized with Pierce ECL Plus Western Blotting Substrate (Thermo Fisher Scientific, Inc.).

$\mathrm{H}_{2} \mathrm{O}_{2}$ or cisplatin (CDDP) treatment. Cells were plated at $1 \times 10^{4}$ cells/well in a 96-well NanoCulture Plate (SCIVAX Corporation) after siRNA transfection. A total of 1 day after plating, cells were treated with $\mathrm{H}_{2} \mathrm{O}_{2}(150 \mu \mathrm{M}$; Wako Pure Chemical Industries, Ltd.) or CDDP (5 $\mu \mathrm{M}$; Sigma-Aldrich; Merck $\mathrm{KGaA}$ ) at $37^{\circ} \mathrm{C}$ for 1 or 3 days, respectively. The number of viable cells was counted using a CellTiter-Glo Luminescent Cell Viability Assay (Promega Corporation), according to the manufacturer's protocol.

TGF- $\beta$ treatment. T.Tn cells were plated at $8 \times 10^{5}$ cells/well in a 6 -well plate and were incubated at $37^{\circ} \mathrm{C}$ overnight. Subsequently, the cells were treated with TGF- $\beta 1(10 \mathrm{ng} / \mathrm{ml}$; R\&D Systems, Inc.) at $37^{\circ} \mathrm{C}$ for 3 days.

Statistical analysis. RT-qPCR data are expressed as the mean $\pm S E$ and were analyzed using one-way ANOVA followed by Tukey's honestly significant difference test or Dunnett's multiple comparison test. Recurrence-free survival (RFS) and overall survival (OS) were estimated using the Kaplan-Meier method and were compared using the log-rank test by GraphPad Prism version 7.0a (GraphPad Software, Inc.). RFS was defined as the period from the date of definitive CRT or surgery until the date of death or recurrence, which was clinically confirmed through endoscopy or CECT. OS was defined as the time from the date of definitive CRT or surgery until the last confirmed date of survival or death, regardless of the cause of death. Multivariate analysis with the Cox model was used to investigate the association between patient background, endoscopic findings and clinicopathological factors, including death or recurrence. IBM SPSS statistical software package (version 22.0 for Mac; IBM Japan Ltd.) and Ekuseru-Toukei 
Table I. Primer sequences for reverse transcription-PCR.

\begin{tabular}{|c|c|c|}
\hline Gene & Forward primer ( $5^{\prime}$ to $\left.3^{\prime}\right)$ & Reverse primer ( $5^{\prime}$ to $\left.3^{\prime}\right)$ \\
\hline$A C T B$ & GAAGTCCCTTGCCATCCTAA & GCACGAAGGCTCATCATTCA \\
\hline$C D 24$ & GCCTCGACACACATAAACCT & CTGTTCGATCTGTTTGTTCC \\
\hline$S I M 2^{\mathrm{a}}$ & TGCCAACCCTGTGTCACTTA & ACCCTCGGCTTATTTCCTGT \\
\hline$S I M 2^{\mathrm{b}}$ & СТTCССТСТGGACTCTCACG & AGGCTGTGCCTAGCAGTGTT \\
\hline KRT4 & CAGGAGTGTCATCTCCAGAA & GAAGATTCACCTGCAGATGG \\
\hline SNAI2 & TAGGAAGAGATCTGCCAGAC & CCCCAAGGCACATACTGTTA \\
\hline VIM & GCTTTCAAGTGCCTTTCTGC & GTTGGTTGGATACTTGCTGG \\
\hline $\mathrm{CDH} 2$ & GGCATAGTCTATGGAGAAGT & GATTTCACAAGTCTTCACCTG \\
\hline TWIST1 & GCATTTTACCATGGGTCCTC & ATACTGGGATCAAACTGGCC \\
\hline TWIST2 & GAGCCTCTGCATGATTGTTTC & CACTGCAGTCACTTAGCTTG \\
\hline SOD2 & ATGATCCCAGCAAGATAATG & AGGACCTTATAGGGTTTTCAG \\
\hline
\end{tabular}

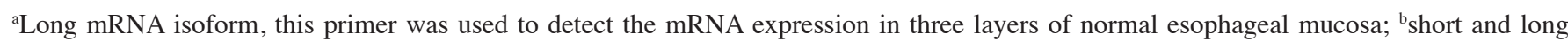
mRNA isoforms, this primer was used to detect the mRNA expression in plasmid- and siRNA-transfected T.Tn cells. ACTB, $\beta$-actin; $C D H 2$, cadherin 2; KRT4, keratin 4; SNAI2, snail family transcriptional repressor 2; VIM, vimentin.

2010 (Social Survey Research Information Co., Ltd.) were used for statistical analyses. $\mathrm{P}<0.05$ was considered to indicate a statistically significant difference.

\section{Results}

CD24 and KRT4 are differentiation markers that are downstream of SIM2. Initially, this study analyzed the semi-quantitative RT-PCR of CD24, KRT4 and SIM2 in three layers (differentiated, parabasal and basal cell layers) of normal esophageal mucosa (23 cycles for $C D 24,18$ cycles for KRT4 and 24 cycles for SIM2). CD24 and KRT4 were highly expressed in differentiated cell layers and moderately expressed in parabasal cell layers. SIM2 was highly expressed in parabasal and basal cell layers, and moderately expressed in differentiated cell layers (Figs. 1A and S1). Subsequently, CD24, CK4 and SIM2 protein expression was detected in normal esophageal mucosa by IHC. In accordance with the RT-PCR results, CD24 and CK4 were highly expressed in differentiated and parabasal cell layers, whereas SIM2 was expressed highly in parabasal and basal cell layers (Fig. 1B). These data suggested that CD24 and CK4 are differentiation markers in the stratified squamous epithelia of the esophagus.

To investigate whether $C D 24$ and KRT4 are downstream genes of the tumor differentiation-inducer SIM2, a 3D culture system was used, which has been reported to induce differentiation of ESCC through adhesion restriction (13). Overexpression of SIM2 in T.Tn cells followed by 3D culture has been reported to increase spheroid formation (13); in this study, SIM2 overexpression and 3D culture significantly increased $C D 24$ and KRT4 mRNA expression at day 8 (Fig. 1C). These results of in vitro $3 \mathrm{D}$ cell culture suggested that $C D 24$ and KRT4 may be downstream differentiation markers of SIM2.

Patients with ESCC and high CD24 and KRT4 mRNA expression exhibit a favorable prognosis with definitive CRT. Clinicopathological characteristics of patients with ESCC who received definitive CRT $(n=81)$ or surgical resection $(n=63)$ are shown in Table SI. Using our previously obtained microarray data (GSE69925) (4), CD24 and KRT4 mRNA expression was examined in biopsy specimens from 81 patients with ESCC (clinical stages II and III) prior to definitive CRT. A total of 15 of the 81 cases $(18.5 \%)$ were classified into a high CD24 mRNA expression group, whose $C D 24$ expression was higher than mean + SD (Fig. 2A). Similarly, 22 of the 81 cases (27\%) were classified into a high KRT4 mRNA expression group, whose KRT4 expression signal intensity was $>50,000$ (Fig. 2A). Kaplan-Meier analysis revealed that RFS and OS of the high CD24 or KRT4 mRNA expression groups were significantly longer than those of the low $C D 24$ or KRT4 mRNA expression groups (CD24, lower than mean-SD and KRT4, signal intensity was $<1,000$ ) (Fig. 2B and C).

Immunohistochemical analyses for predicting patients with ESCC with a favorable prognosis following definitive CRT. According to the microarray data, CD24 and KRT4 mRNA expression may be candidate markers for predicting patients with ESCC with a favorable prognosis in response to definitive CRT. The CD24 and KRT4 genes encode CD24 and CK4 proteins, respectively. To verify the results of microarray analysis, each of these two marker proteins was examined by immunohistochemical staining in biopsy specimens obtained from 81 patients with ESCC prior to definitive CRT. Representative data are shown in Fig. 3A. According to the cut-off values for CD24 and CK4 positivity rates, a sensitivity test was performed using the hazard ratio (HR) for OS. The minimum HR was obtained when the cut-off values of 20\% CD24-positive and 10\% CK4-positive in tumor cells were adopted (CD24: HR, 0.446; 95\% CI, 0.219-0.909; $\mathrm{P}=0.026$ and CK4: HR, 0.176; 95\% CI, 0.042-0.728; $\mathrm{P}=0.016)$. High CD24 expression was detected in 26 of the 81 patients (32\%), whereas high CK4 expression was detected in 14 of the 81 patients (17\%) (Table II). As shown in Fig. 3B, RFS and OS of patients with ESCC and high CD24 or CK4 protein expression were significantly higher than those of patients with ESCC and low CD24 or CK4 protein expression. Only 10 patients with ESCC exhibited high expression of both CD24 and CK4, whereas 71 patients with ESCC 
A

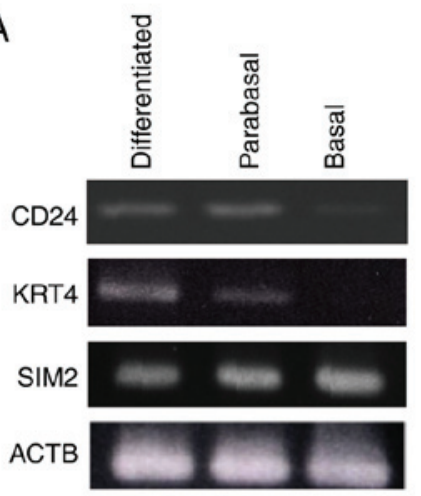

B

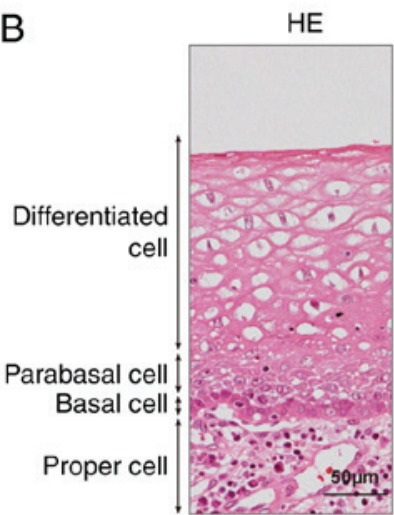

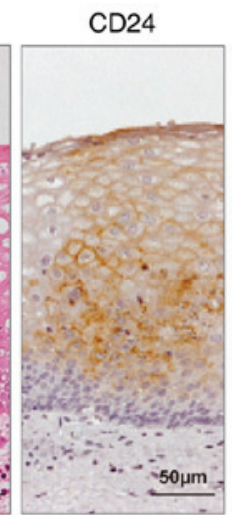

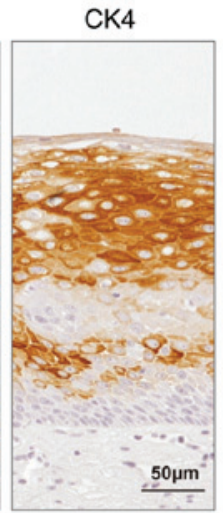
SIM2

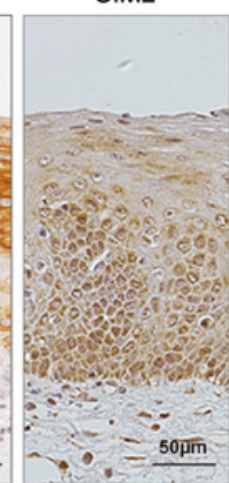

C

SIM2
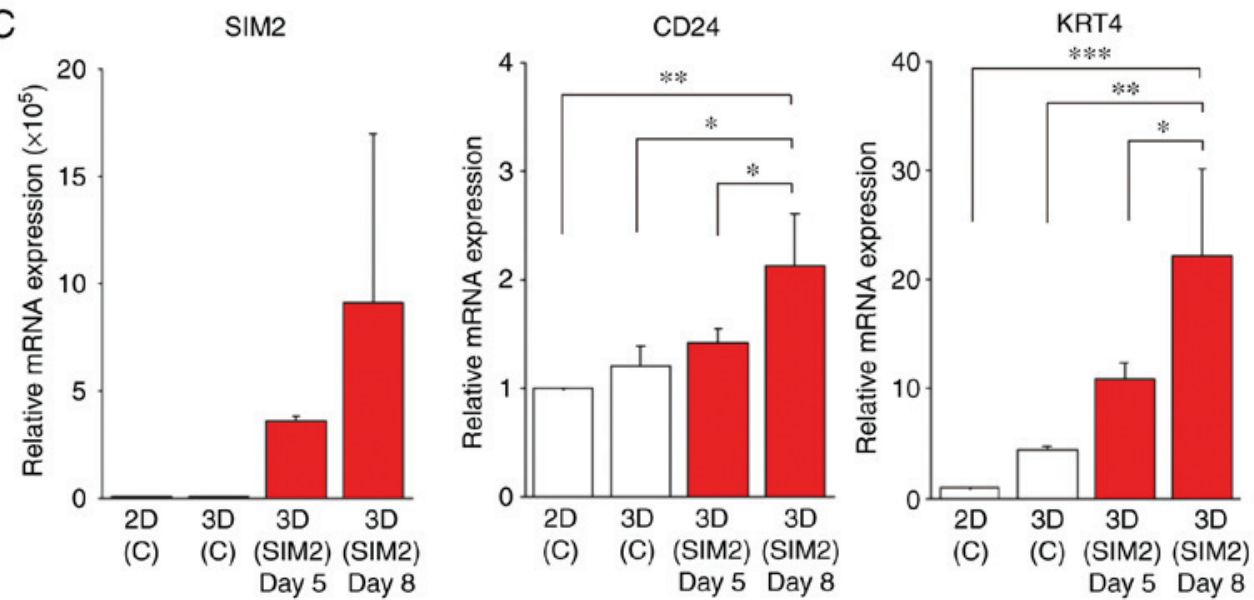

Figure 1. CD24 and CK2, which is encoded by KRT4, are differentiation markers regulated by SIM2. (A) Semi-quantitative RT-PCR of CD24 and KRT4 in three layers (differentiated, parabasal and basal cell layers) of the normal esophageal mucosa. (B) Immunohistochemical staining of CD24, CK4 and SIM2 in the normal esophageal mucosa; representative images are indicated. (C) RT-PCR of SIM2, CD24 and KRT4 in 3D-cultured T.Tn cells 5 or 8 days after empty vector or SIM2 transfection $(\mathrm{n}=3$, mean $\pm \mathrm{SE}) .{ }^{*} \mathrm{P}<0.05,{ }^{* *} \mathrm{P}<0.01$ and ${ }^{* * *} \mathrm{P}<0.001$. ACTB, $\beta$-actin; CK4, cytokeratin 4 ; HE, hematoxylin and eosin; KRT4, keratin 4; RT-PCR, reverse transcription-PCR; SIM2, SIM bHLH transcription factor 2.

exhibited low expression of both CD24 and CK4. Patients with high CD24 + CK4 expression survived longer than patients with low CD24 + CK4 expression (Fig. 3B).

Multivariate Cox regression analysis in 81 patients with ESCC revealed that high CD24 or CK4 expression was an independent favorable prognostic factor in response to definitive CRT for RFS (CD24: HR, 0.451; 95\% CI, 0.204-0.997; $\mathrm{P}=0.049$ and CK4: HR, 0.289; 95\% CI, 0.009-0.960; $\mathrm{P}=0.043$ ) and OS (CD24: HR, 0.281; 95\% CI, 0.108-0.732; P=0.009 and CK4: HR, 0.119; 95\% CI, 0.016-0.894; $\mathrm{P}=0.039$ ) (Table II). Tumor differentiation type (tissue type) of biopsy specimens was also revealed to be an independent favorable prognostic factor for OS, but not for DFS, in response to definitive CRT (Table II). In accordance with CD24 and CK4 being differentiation markers (Fig. 1), ESCC samples with high CD24 or CK4 expression, particularly CD24, divided preferentially into well or moderately differentiated cancer (Table SII).

CD24 and CK4 are predictive biomarkers for definitive CRT and surgery. Based on the clinicopathological characteristics of the patients (Table SI), 81 patients with ESCC undergoing CRT were compared with 63 patients with ESCC undergoing surgery. Kaplan-Meier analyses revealed that when CD24 was highly expressed, there was no significant difference in the RFS and OS of 26 patients with ESCC undergoing definitive CRT compared with the 33 patients with ESCC undergoing surgery. Conversely, when CD24 was lowly expressed, there was a significant difference between the RFS and OS of 55 patients with ESCC undergoing definitive CRT and those of 30 patients with ESCC undergoing surgery (Fig. 4A). Although there were more patients with CK4 high expression in the CRT group, when CK4 was highly expressed, there was no significant difference in the RFS and OS of patients undergoing definitive CRT compared with those undergoing surgery (Fig. 4B). Conversely, when CK4 was lowly expressed, there was a significant difference in the RFS and OS of patients undergoing CRT compared with those undergoing surgery (Fig. 4B). As shown in Tables III and IV, multivariate Cox regression analysis in patients with ESCC and low CD24 or CK4 expression indicated that there was a significant difference between patients undergoing definitive CRT and those undergoing surgery in RFS (low CD24 HR, 2.28; 95\% CI, 1.182-4.397; P=0.014 and low CK4: HR, 2.142; 95\% CI, 1.274-3.599; $\mathrm{P}=0.004)$ and $\mathrm{OS}$ (low CD24: HR, 3.781; 95\% CI, 1.518-9.416; $\mathrm{P}=0.004$ and low CK4: HR, 2.407; 95\% CI, 1.317-4.399; $\mathrm{P}=0.004$ ). However, in patients with ESCC and high CD24 or CK4, there was no significant difference between RFS and OS between CRT and surgery (data not shown). Taken together, in cases with low 
A

CD24

$$
\text { (81 cases) }
$$

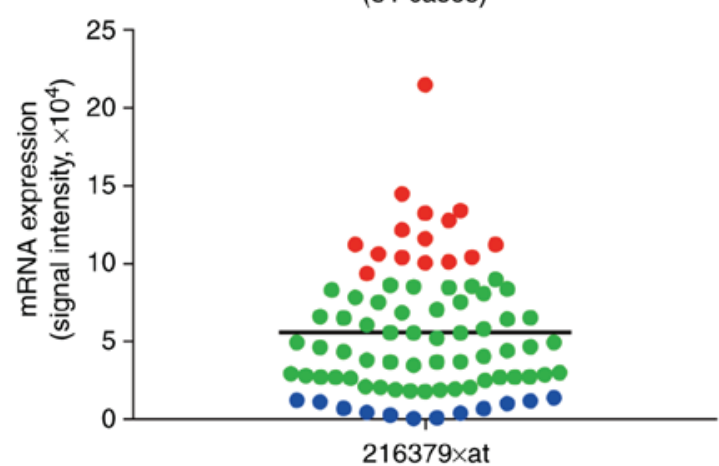

$\mathrm{B}$

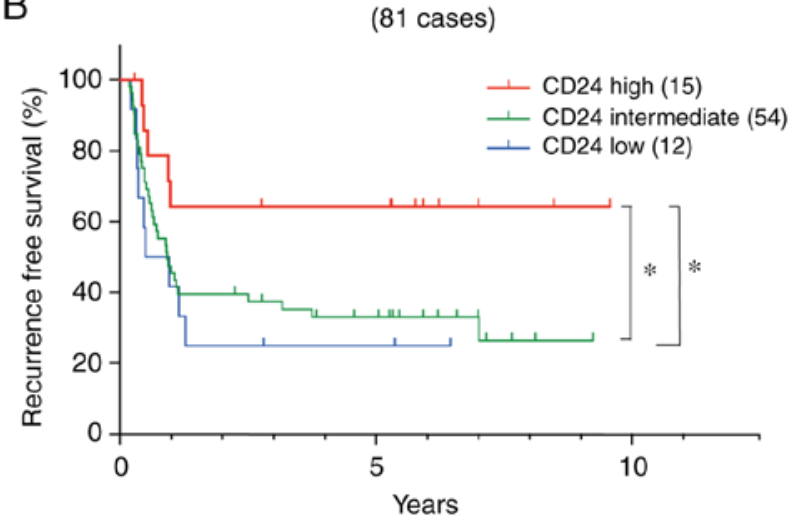

OS

C

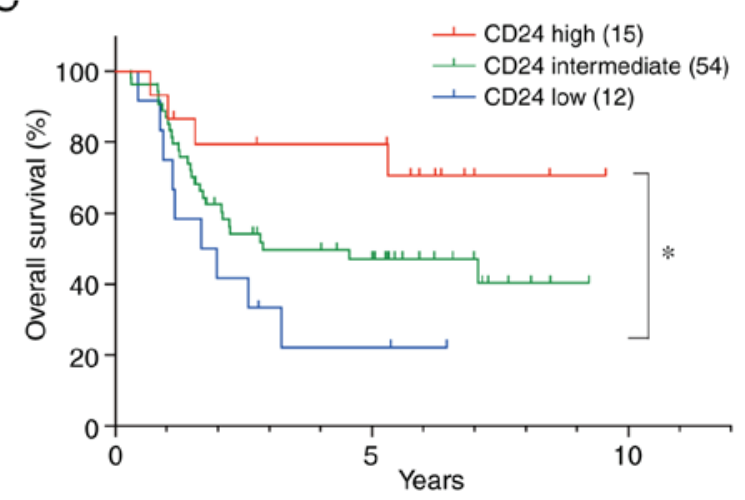

KRT4

(81 cases)

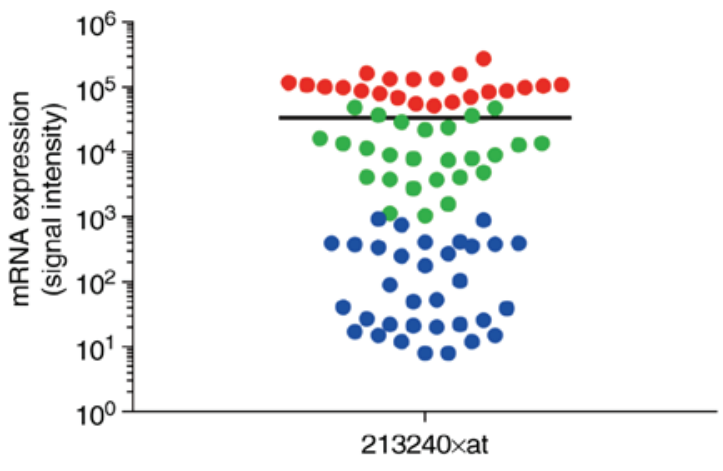

RFS

(81 cases)

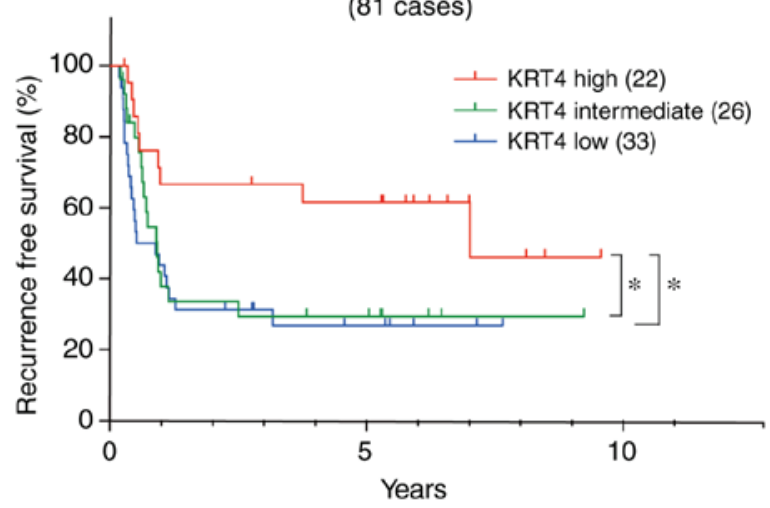

OS

(81 cases)

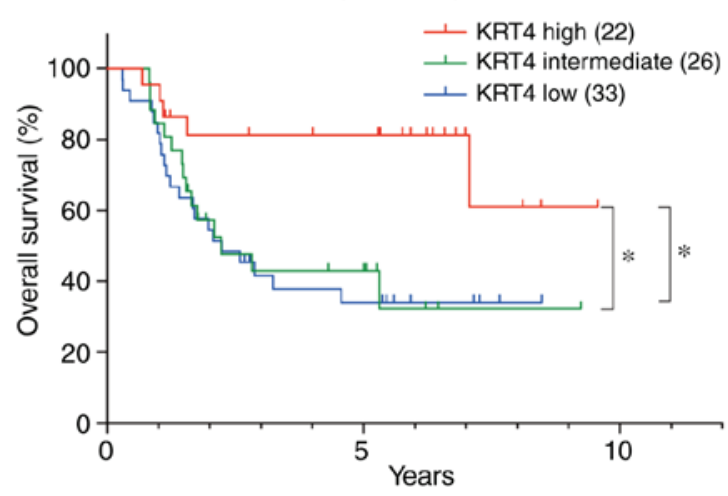

Figure 2. Patients with ESCC and high CD24 and KRT4 mRNA expression exhibit a favorable prognosis with definitive CRT. (A) Using our microarray data (GSE69925), CD24 and KRT4 mRNA expression was examined in 81 biopsy specimens prior to definitive CRT. A total of 15 of the 81 cases (18.5\%) were classified into a high $C D 24$ expression group (red, expression was higher than the mean \pm SD). Similarly, 22 of the 81 cases (27\%) were classified into a high KRT4 expression group (red, expression was $>50,000$ in signal intensity). Bar indicates the mean. (B and C) Kaplan-Meier analysis revealed that RFS and OS of the high CD24 and KRT4 expression groups were significantly longer than those of the low CD24 and KRT4 expression groups (blue, CD24 expression was lower than the mean-SD; KRT4, expression was $<1,000$ in signal intensity). "P $<0.05$. KRT4, keratin 4; OS, overall survival; RFS, recurrence-free survival.

CD24 or CK4, surgery was revealed to be a good therapeutic modality compared with definitive CRT.

CD24 is associated with radiosensitivity through superoxide dismutase 2 (SOD2) suppression, but not chemosensitivity in ESCC cells. In the present study, microarray and IHC analyses of biopsy specimens from 81 patients with ESCC prior to definitive CRT revealed that if CD24 mRNA or protein was highly expressed, RFS and OS were better (Figs. 2 and 3). Furthermore, we recently reported that SIM2 expression was associated with a favorable prognosis of patients with ESCC undergoing definitive CRT, and that SIM2 was involved in chemosensitivity through suppression of numerous DNA repair genes (X-ray repair cross complementing 5, BRCA1 DNA repair-associated, FA complementation group D2 and BRCA1-asssociated RING domain 1) and radiosensitivity through antioxidant gene (SOD2) suppression (13). These findings indicated that CD24 may be directly involved in chemosensitivity and/or radiosensitivity. RT-qPCR was carried out using two CD24 siRNAs (CD24-s2615 and CD24-s2616), and a decrease in CD24 

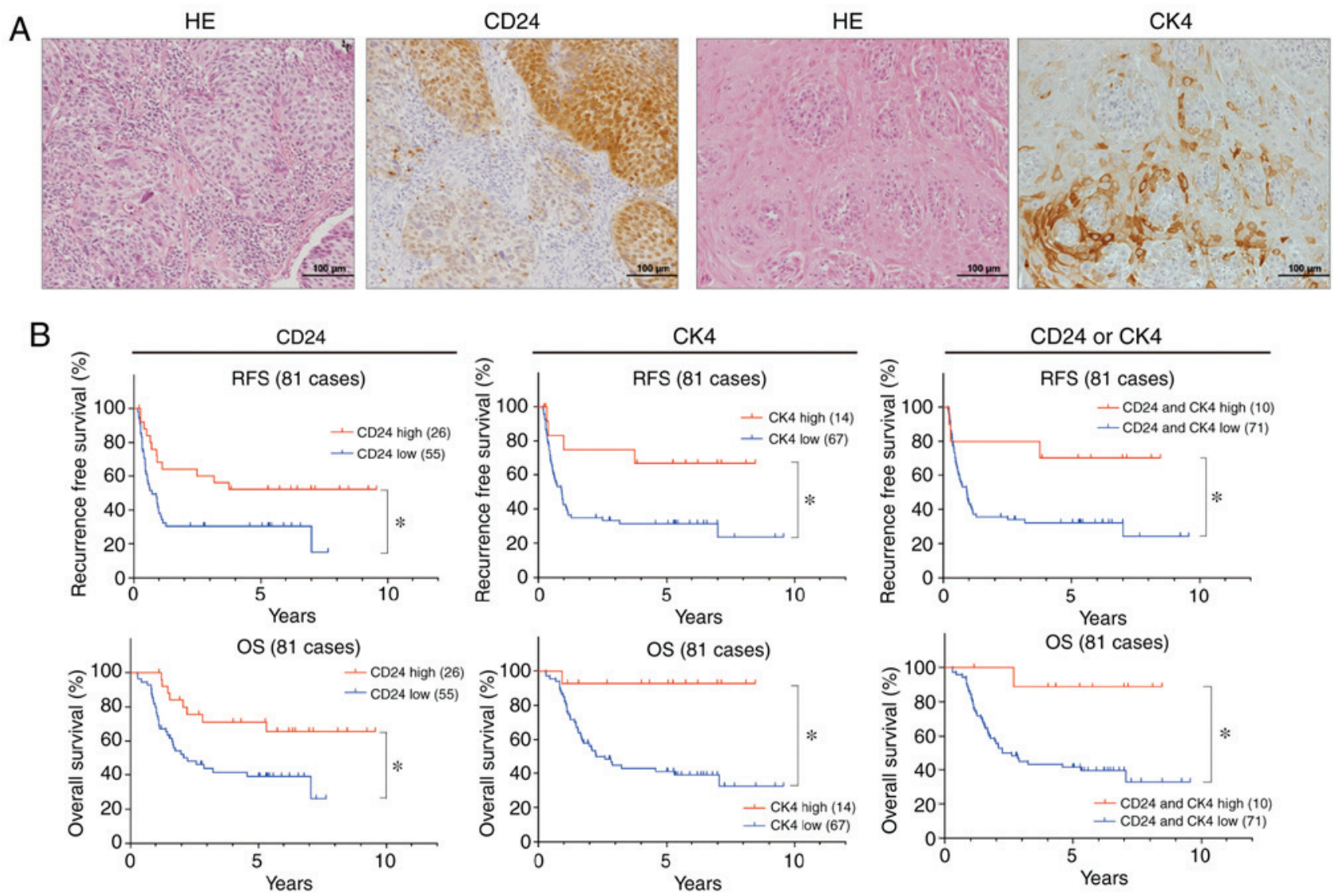

Figure 3. Patients with ESCC and high CD24 and CK4 protein expression exhibit a favorable prognosis with definitive CRT. (A) Representative immunohistochemical staining of CD24 and CK4. (B) High CD24 expression (>20\% positive) was detected in 26 out of 81 patients (32\%), whereas high CK4 expression (>10\% positive) was detected in 14 out of 81 patients (17\%). RFS and OS of patients with high CD24 or CK4 expression were significantly higher than those of patients with low CD24 or CK4 expression. In addition, 10 patients with high CD24 + CK4 expression survived longer than the 71 patients with low CD24 + CK4 expression. " $\mathrm{P}<0.05$. CK4, cytokeratin 4; HE, hematoxylin and eosin; OS, overall survival; RFS, recurrence-free survival.

mRNA expression was confirmed (Fig. 5A). Accordingly, CD24 protein expression was also decreased by CD24 siRNA (Fig. 5A). To examine the hypothesis that CD24 is involved in CRT sensitivity, control siRNA-, CD24 siRNA (s2615)- and CD24 siRNA (s2616)-transfected T.Tn cells were treated with CDDP, which is used in the standard chemotherapy regimen of ESCC, for 3 days in a 3D culture. The viable ratio of CD24 siRNA (s2615)- or CD24 siRNA (s2616)-transfected T.Tn cells was not significantly decreased compared with control siRNA-transfected T.Tn cells (Fig. 5B), suggesting that CD24 was not involved in chemosensitivity. However, CD24 siRNA (s2615)- or CD24 siRNA (s2616)-transfected T.Tn cells exhibited increased SOD2 mRNA expression compared with in the control siRNA-transfected T.Tn cells (Fig. 5C). In addition, CD24 siRNAs were transfected into T.Tn cells and cell viability was investigated after $\mathrm{H}_{2} \mathrm{O}_{2}$ treatment. $C D 24$ siRNA (s2615)- or CD24 siRNA (s2616)-transfected T.Tn cells exhibited significantly increased viability following $\mathrm{H}_{2} \mathrm{O}_{2}$ treatment compared with in the control siRNA-transfected T.Tn cells (Fig. 5D). These findings indicated that CD24 may be involved in radiosensitivity through SOD2 suppression, but not in chemosensitivity (Fig. 6).

\section{Discussion}

Although definitive CRT improves the prognosis of patients with ESCC and is an important modality, $40 \%$ of patients exhibit persistent disease or experience recurrence, resulting in poor long-term survival (2). Therefore, predictive biomarkers are needed to select patients who are potentially curable with definitive CRT. Since preoperative treatment is increasing for patients with solid tumors, biopsy specimens of such patients are the only material available that may be used to predict the effect of neoadjuvant therapy. Great efforts have been made to identify such predictive biomarkers by numerous researchers; however, few studies exist that have identifed biomarkers for definitive CRT using biopsy specimens from patients with ESCC $(4,33)$. In this study, it was demonstrated that CD24 and CK4 have great potential to be independent predictive biomarkers for such patients. Our recent study reported that SIM2 in ESCC was a key transcription factor involved in tumor cell differentiation and was associated with a good response to CRT (13). This study revealed that CD24 and KRT4, which encodes CK4, were differentiation markers, which were upregulated by SIM2. Therefore, CD24 and KRT4 may be downstream differentiation markers of SIM2, and similar to SIM2, they may serve a role in CRT sensitivity.

Kaplan-Meier analyses revealed that RFS and OS in the high $C D 24$ and KRT4 mRNA expression groups were significantly longer than those in the low CD24 and KRT4 mRNA expression groups. In addition, immunohistochemical analyses were conducted, and the power of CD24 and CK4 for predicting patients with ESCC and a favorable prognosis 
Table II. Multivariate analysis of RFS and OS in patients with ESCC undergoing definitive CRT.

\begin{tabular}{|c|c|c|c|c|c|c|c|}
\hline \multirow[b]{2}{*}{ Variable } & \multirow[b]{2}{*}{ n $(\%)$} & \multicolumn{3}{|c|}{ RFS } & \multicolumn{3}{|c|}{ OS } \\
\hline & & Hazard ratio & $95 \% \mathrm{CI}$ & P-value & Hazard ratio & $95 \% \mathrm{CI}$ & P-value \\
\hline \multicolumn{8}{|l|}{ Age } \\
\hline$<60$ years & $21(25.9)$ & Reference & $0.468-1.976$ & 0.914 & Reference & $0.776-2.958$ & 0.528 \\
\hline$\geq 60$ years & $60(74.1)$ & 0.961 & & 0.62 & 0.764 & & \\
\hline \multicolumn{8}{|l|}{ Sex } \\
\hline Male & $74(91.3)$ & Reference & $0.474-3.470$ & 0.624 & Reference & $0.585-5.368$ & 0.311 \\
\hline Female & $4(8.7)$ & 1.283 & & & 1.772 & & \\
\hline \multicolumn{8}{|c|}{ Macroscopic type } \\
\hline Types 1 and 2 & $50(61.7)$ & Reference & $0.572-1.934$ & 0.87 & Reference & $0.776-2.958$ & 0.224 \\
\hline Type 3 & $31(38.3)$ & 1.052 & & & 1.515 & & \\
\hline \multicolumn{8}{|l|}{ Tissue type } \\
\hline $\mathrm{W} / \mathrm{D}$ and $\mathrm{M} / \mathrm{D}$ & $68(84.0)$ & Reference & $0.658-3.518$ & 0.327 & Reference & $1.045-7.294$ & $0.041^{\mathrm{a}}$ \\
\hline $\mathrm{P} / \mathrm{D}$ & $13(16.0)$ & 1.521 & & & 2.76 & & \\
\hline \multicolumn{8}{|l|}{ Location } \\
\hline Ut and Mt & $45(55.6)$ & Reference & $0.420-1.441$ & 0.425 & Reference & $0.416-1.555$ & 0.518 \\
\hline $\mathrm{Lt}$ & $36(44.4)$ & 0.778 & & & 0.805 & & \\
\hline \multicolumn{8}{|l|}{ Circumference } \\
\hline$<3 / 4$ & $45(55.6)$ & Reference & $0.822-2.761$ & 0.185 & Reference & $0.975-3.618$ & 0.06 \\
\hline$\geq 3 / 4$ & $36(44.4)$ & 1.507 & & & 1.878 & & \\
\hline \multicolumn{8}{|l|}{ c T factor } \\
\hline $\mathrm{T} 2$ & $16(19.8)$ & Reference & $0.479-2.732$ & 0.762 & Reference & $0.544-3.459$ & 0.503 \\
\hline T3 & $65(80.2)$ & 1.144 & & & 1.372 & & \\
\hline \multicolumn{8}{|l|}{ c N factor } \\
\hline Absent & $38(46.9)$ & Reference & $0.927-3.608$ & 0.082 & Reference & $0.737-3.281$ & 0.247 \\
\hline Present & $43(53.1)$ & 1.828 & & & 1.555 & & \\
\hline \multicolumn{8}{|l|}{ CD24 } \\
\hline Low & $55(67.9)$ & Reference & $0.204-0.997$ & $0.049^{\mathrm{a}}$ & Reference & $0.108-0.732$ & $0.009^{\mathrm{a}}$ \\
\hline High & $26(32.1)$ & 0.451 & & & 0.281 & & \\
\hline \multicolumn{8}{|l|}{ CK4 } \\
\hline Low & 67 (82.7) & Reference & $0.009-0.960$ & $0.043^{\mathrm{a}}$ & Reference & $0.016-0.894$ & $0.039^{\mathrm{a}}$ \\
\hline High & $14(17.3)$ & 0.289 & & & 0.119 & & \\
\hline
\end{tabular}

CK4, cytokeratin 4; OS, overall survival; c T, clinical Tumor; c N, clinical Node; Lt, lower thoracic; M/D, moderately differentiated; Mt, middle thoracic; P/D, poorly differentiated; RFS, recurrence-free survival; Ut, upper thoracic; W/D, well differentiated. ${ }^{\mathrm{P}}<0.05$.

in response to definitive CRT was evaluated. Multivariate Cox regression analyses revealed that high CD24 or CK4 expression was an independent favorable prognostic factor in patients undergoing definitive CRT. Notably, when CD24 or CK4 were highly expressed, there was no significant difference in RFS and OS between patients undergoing definitive CRT and those undergoing surgery. However, when CD24 or CK4 were lowly expressed, there was a significant difference in RFS and OS between patients undergoing definitive CRT and those undergoing surgery. Multivariate Cox regression analyses also indicated a significant difference in RFS and OS between patients undergoing definitive CRT and those undergoing surgery. During this study, discrepancies between mRNA and protein levels were detected in some individual cases. In high or low mRNA expression groups, these discrepancies are likely decreased if intermediate cases are removed from these groups, as one microarray analysis may have variability, particularly in cases with intermediate mRNA levels; therefore, cases were divided into three groups with regards to mRNA level (high, intermediate and low). In summary, for patients with ESCC and low CD24 or CK4 expression, it may be stated that surgery is preferable to definitive CRT. There were no significant changes in RFS and OS between patients undergoing definitive CRT and those undergoing surgery in the high CD24 or high CK4 groups; however, definitive CRT, which preserves organs, may be preferable for such patients.

In previous studies, CD24 overexpression has been reported to be markedly associated with a more aggressive 
A
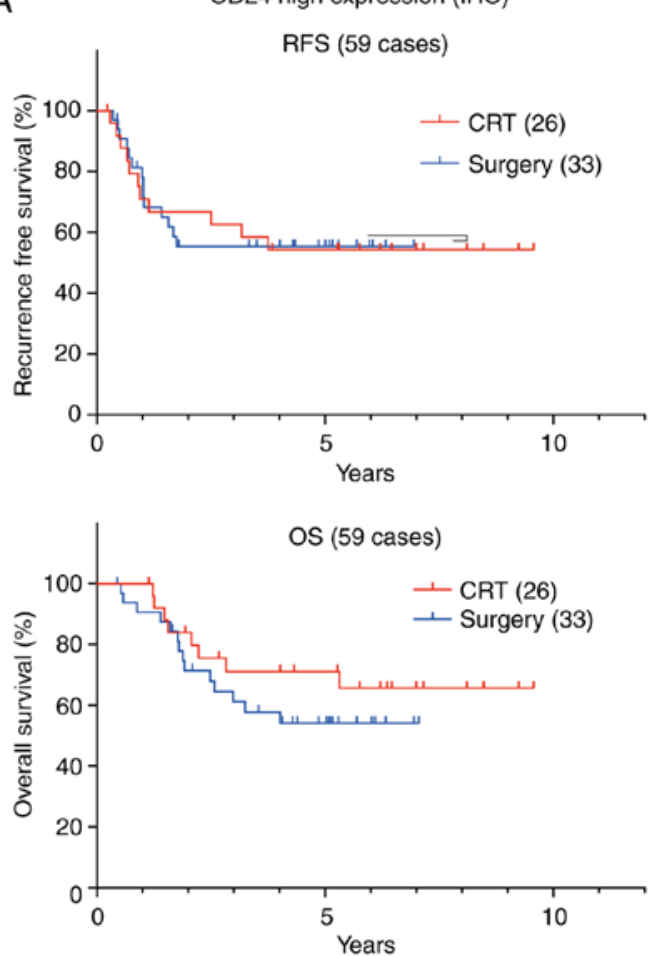

B
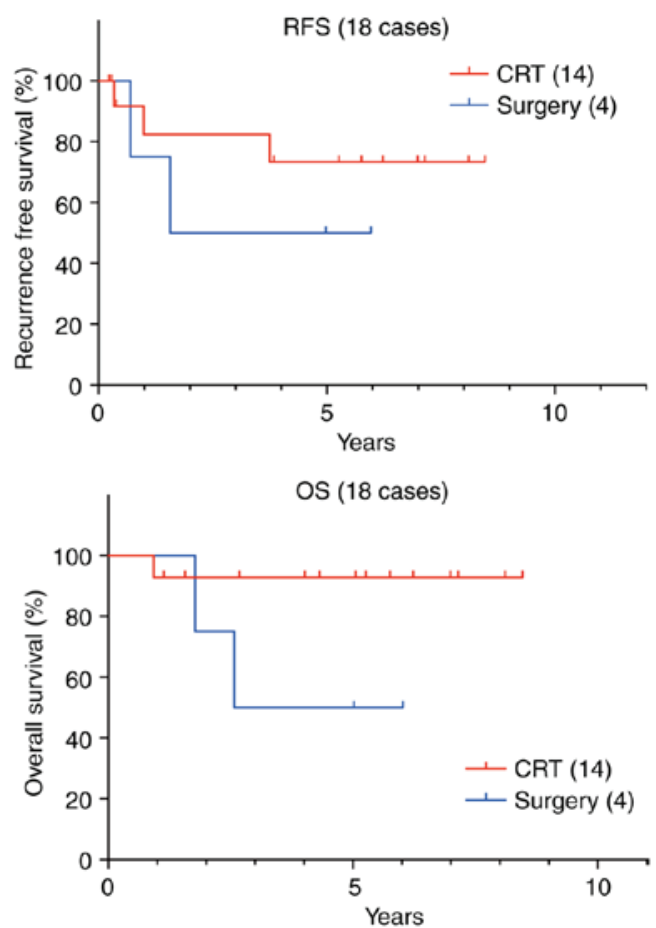

CD24 low expression (IHC)

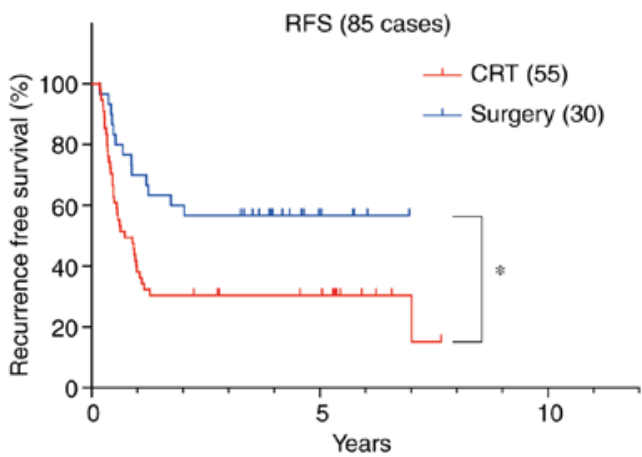

OS (85 cases)

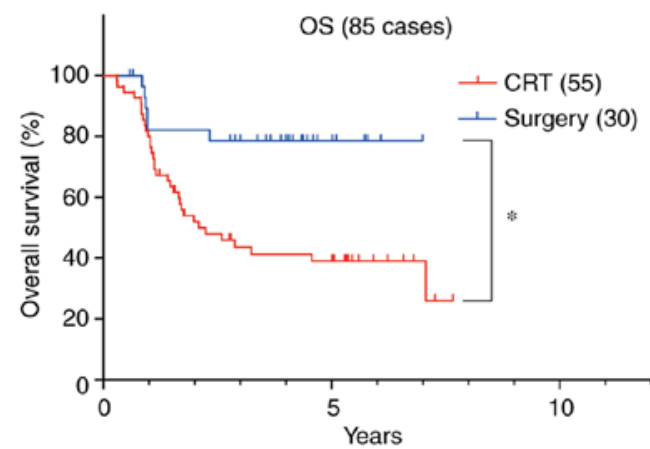

CK4 low expression (IHC)

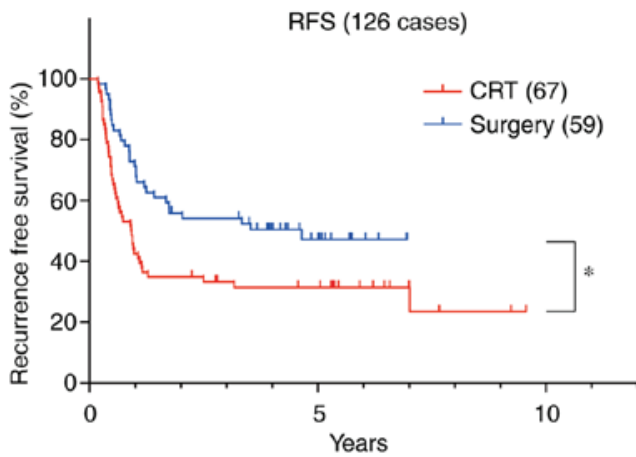

OS (126 cases)

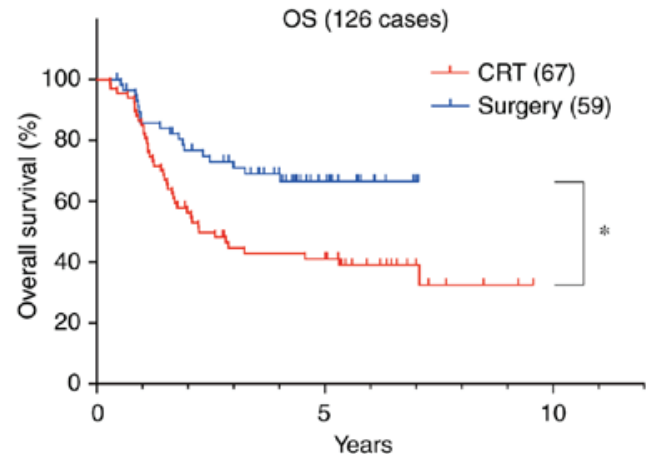

Figure 4. CD24 and CK4 are predictive biomarkers for definitive CRT and surgery. (A) Based on CD24 and CK4 protein expression, prognosis was compared between 81 patients with ESCC undergoing CRT and 63 patients with ESCC undergoing surgery. In patients with high CD24 expression, there was no significant difference in RFS and OS between 26 patients undergoing definitive CRT and 33 patients undergoing surgery, whereas in patients with low CD24 expression, there was a significant difference in RFS and OS between 55 patients undergoing definitive CRT and 30 patients undergoing surgery. (B) Similarly, in patients with high CK4 expression, there was no significant difference in RFS and OS between 14 patients undergoing definitive CRT and four patients undergoing surgery, whereas in patients with low CK4 expression, there was a significant difference in RFS and OS between 67 patients undergoing definitive CRT and 59 patients undergoing surgery. "P<0.05. CK4, cytokeratin; CRT, chemoradiotherapy; IHC, immunohistochemistry; OS, overall survival; RFS, recurrence-free survival.

course of disease (15-18). CD24 may have a role in breast cancer metastasis (19-21) and has been identified as a significant poor prognostic factor (34). In ovarian cancer, CD24 is a key molecule in epithelial-mesenchymal transition 
Table III. Multivariate analysis of RFS and OS in patients with low CD24 expression.

\begin{tabular}{|c|c|c|c|c|c|c|c|}
\hline \multirow[b]{2}{*}{ Variable } & \multirow[b]{2}{*}{$\mathrm{n}(\%)$} & \multicolumn{3}{|c|}{ RFS } & \multicolumn{3}{|c|}{ OS } \\
\hline & & Hazard ratio & $95 \% \mathrm{CI}$ & P-value & Hazard ratio & $95 \% \mathrm{CI}$ & P-value \\
\hline \multicolumn{8}{|l|}{ Age } \\
\hline $\begin{array}{l}<60 \text { years } \\
\geq 60 \text { years }\end{array}$ & $\begin{array}{l}18(21.2) \\
67(78.8)\end{array}$ & $\begin{array}{c}\text { Reference } \\
1.2\end{array}$ & $0.559-2.573$ & 0.64 & $\begin{array}{c}\text { Reference } \\
1.082\end{array}$ & $0.453-2.582$ & 0.86 \\
\hline Sex & & & & & & & \\
\hline $\begin{array}{l}\text { Male } \\
\text { Female }\end{array}$ & $\begin{array}{l}75(88.2) \\
10(11.8)\end{array}$ & $\begin{array}{c}\text { Reference } \\
1.089\end{array}$ & $0.421-2.822$ & 0.86 & $\begin{array}{c}\text { Reference } \\
1.931\end{array}$ & $0.723-5.161$ & 0.189 \\
\hline $\begin{array}{l}\text { Macroscopic typ } \\
\text { Types } 1 \text { and } 2 \\
\text { Type } 3\end{array}$ & $\begin{array}{l}51(60.0) \\
34(40.0)\end{array}$ & $\begin{array}{c}\text { Reference } \\
1.048\end{array}$ & $0.588-1.867$ & 0.874 & $\begin{array}{c}\text { Reference } \\
1.798\end{array}$ & $0.930-3.474$ & 0.081 \\
\hline $\begin{array}{l}\text { Tissue type } \\
\text { W/D and M/D } \\
\text { P/D }\end{array}$ & $\begin{array}{l}75(88.2) \\
10(11.8)\end{array}$ & $\begin{array}{c}\text { Reference } \\
1.181\end{array}$ & $0.488-2.857$ & 0.721 & $\begin{array}{c}\text { Reference } \\
2.328\end{array}$ & $0.924-5.869$ & 0.073 \\
\hline $\begin{array}{l}\text { Location } \\
\text { Ut and Mt } \\
\text { Lt }\end{array}$ & $\begin{array}{c}78 \text { (91.8) } \\
7(8.2)\end{array}$ & $\begin{array}{c}\text { Reference } \\
1.254\end{array}$ & $0.707-2.224$ & 0.439 & $\begin{array}{c}\text { Reference } \\
1.288\end{array}$ & $0.666-2.493$ & 0.452 \\
\hline $\begin{array}{l}\text { Circumference } \\
<3 / 4 \\
\geq 3 / 4\end{array}$ & $\begin{array}{l}49(57.6) \\
36(42.4)\end{array}$ & $\begin{array}{c}\text { Reference } \\
1.557\end{array}$ & $0.858-2.826$ & 0.145 & $\begin{array}{c}\text { Reference } \\
2.005\end{array}$ & $0.995-4.040$ & 0.052 \\
\hline $\begin{array}{l}\text { c T factor } \\
\text { T2 } \\
\text { T3 }\end{array}$ & $\begin{array}{l}14(16.5) \\
71(83.5)\end{array}$ & $\begin{array}{c}\text { Reference } \\
1.896\end{array}$ & $0.759-4.734$ & 0.171 & $\begin{array}{c}\text { Reference } \\
1.233\end{array}$ & $0.453-3.356$ & 0.682 \\
\hline $\begin{array}{l}\mathrm{c} \mathrm{N} \text { factor } \\
\text { Absent } \\
\text { Present }\end{array}$ & $\begin{array}{l}41(48.2) \\
44(51.8)\end{array}$ & $\begin{array}{c}\text { Reference } \\
1.103\end{array}$ & $0.601-2.024$ & 0.751 & $\begin{array}{c}\text { Reference } \\
1.128\end{array}$ & $0.560-2.274$ & 0.736 \\
\hline $\begin{array}{l}\text { Treatment } \\
\text { Surgery } \\
\text { CRT }\end{array}$ & $\begin{array}{l}30(35.3) \\
55(64.7)\end{array}$ & $\begin{array}{c}\text { Reference } \\
2.28\end{array}$ & $1.182-4.397$ & $0.014^{\mathrm{a}}$ & $\begin{array}{c}\text { Reference } \\
3.781\end{array}$ & $1.518-9.416$ & $0.004^{\mathrm{a}}$ \\
\hline
\end{tabular}

CRT, chemoradiotherapy; OS, overall survival; c T, clinical Tumor; c N, clinical Node; Lt, lower thoracic; M/D, moderately differentiated; Mt, middle thoracic; P/D, poorly differentiated; RFS, recurrence-free survival; Ut, upper thoracic; W/D, well differentiated. ${ }^{\text {P }}<0.05$.
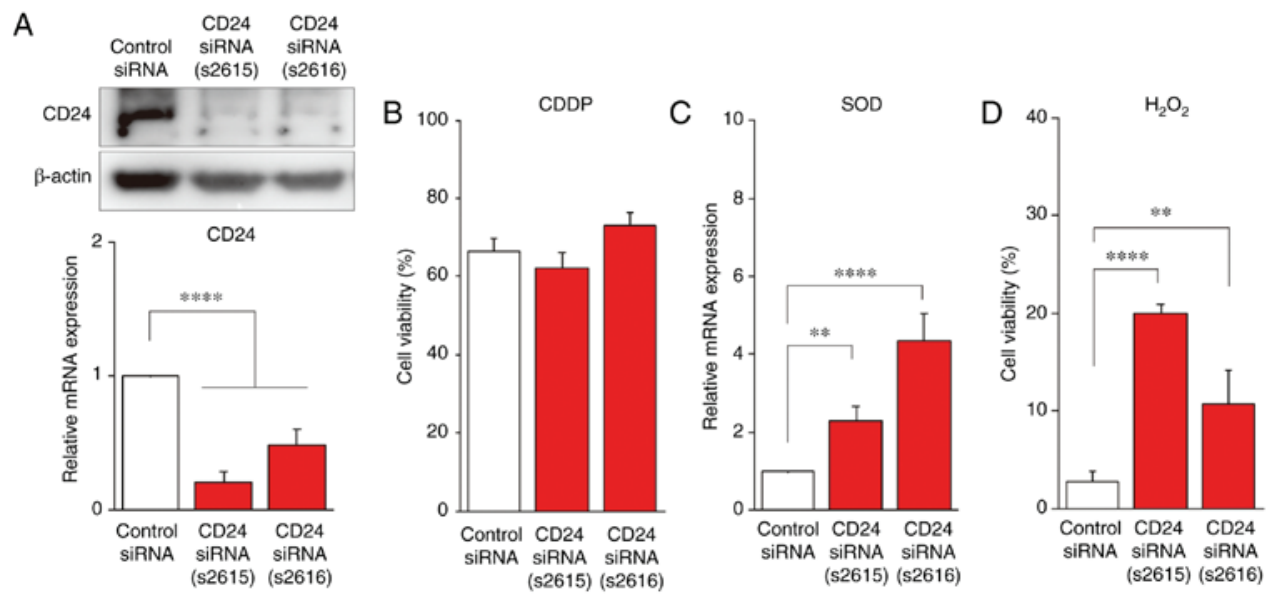

Figure 5. CD24 is involved in radiosensitivity through SOD2 suppression, but not in chemosensitivity of ESCC cells. (A) CD24 protein and CD24 mRNA expression levels were decreased 3 days post-transfection with two CD24 siRNAs (CD24-s2615 and CD24-s2616) (n=3, mean \pm SE). (B) Viability of T.Tn cells treated with CDDP 3 days post-transfection with CD24 siRNA was not significantly decreased compared with control siRNA-transfected T.Tn cells. (C) SOD2 mRNA expression was increased in CD24 siRNA-transfected T.Tn cells compared with in control siRNA-transfected T.Tn cells (n=3, mean \pm SE). (D) $C D 24$ siRNA-transfected T.Tn cells exhibited significantly increased cell viability 24 h after treatment with $\mathrm{H}_{2} \mathrm{O}_{2}$ compared with in control siRNA-transfected T.Tn cells $(\mathrm{n}=3$, mean $\pm \mathrm{SE}) .{ }^{* *} \mathrm{P}<0.01,{ }^{* * * *} \mathrm{P}<0.001$ and ${ }^{* * * *} \mathrm{P}<0.0001$. CDDP, cisplatin; SOD2, superoxide dismutase 2. 
Table IV. Multivariate analysis of RFS and OS in patients with low CK4 expression.

\begin{tabular}{|c|c|c|c|c|c|c|c|}
\hline \multirow[b]{2}{*}{ Variable } & \multirow[b]{2}{*}{$\mathrm{n}(\%)$} & \multicolumn{3}{|c|}{ RFS } & \multicolumn{3}{|c|}{ OS } \\
\hline & & Hazard ratio & $95 \% \mathrm{CI}$ & P-value & Hazard ratio & $95 \% \mathrm{CI}$ & P-value \\
\hline \multicolumn{8}{|l|}{ Age } \\
\hline$<60$ years & $30(23.8)$ & Reference & $0.689-2.236$ & 0.472 & Reference & $0.604-2.218$ & 0.659 \\
\hline$\geq 60$ years & $96(76.2)$ & 1.241 & & & 1.158 & & \\
\hline \multicolumn{8}{|l|}{ Sex } \\
\hline Male & $111(88.1)$ & Reference & $0.639-2.698$ & 0.459 & Reference & $0.938-4.367$ & 0.072 \\
\hline Female & $15(11.9)$ & 1.313 & & & 2.023 & & \\
\hline \multicolumn{8}{|c|}{ Macroscopic types } \\
\hline Types 1 and 2 & 78 (61.9) & Reference & $0.626-1.688$ & 0.913 & Reference & $0.371-1.100$ & 0.106 \\
\hline Type 3 & $48(38.1)$ & 1.028 & & & 0.639 & & \\
\hline \multicolumn{8}{|l|}{ Tissue type } \\
\hline $\mathrm{W} / \mathrm{D}$ and $\mathrm{M} / \mathrm{D}$ & $108(85.7)$ & Reference & $0.508-2.086$ & 0.935 & Reference & $0.380-1.695$ & 0.565 \\
\hline $\mathrm{P} / \mathrm{D}$ & $18(14.3)$ & 1.03 & & & 0.803 & & \\
\hline \multicolumn{8}{|l|}{ Location } \\
\hline Ut and Mt & $69(54.8)$ & Reference & $0.419-1.126$ & 0.137 & Reference & 0.483-1.419 & 0.492 \\
\hline $\mathrm{Lt}$ & $57(45.2)$ & 0.687 & & & 0.828 & & \\
\hline \multicolumn{8}{|l|}{ Circumference } \\
\hline$<3 / 4$ & $68(54.0)$ & Reference & $0.698-1.793$ & 0.64 & Reference & 0.918-2.609 & 0.101 \\
\hline$\geq 3 / 4$ & $58(46.0)$ & 1.119 & & & 1.548 & & \\
\hline \multicolumn{8}{|l|}{ c T factor } \\
\hline $\mathrm{T} 2$ & $26(20.6)$ & Reference & $1.139-4.838$ & $0.021^{\mathrm{a}}$ & Reference & $0.711-3.173$ & 0.286 \\
\hline $\mathrm{T} 3$ & $100(79.4)$ & 2.347 & & & 1.502 & & \\
\hline \multicolumn{8}{|l|}{ c $\mathrm{N}$ factor } \\
\hline Absent & $67(53.2)$ & Reference & $0.748-1.967$ & 0.434 & Reference & $0.557-1.621$ & 0.851 \\
\hline Present & $59(46.8)$ & 1.213 & & & 0.95 & & \\
\hline \multicolumn{8}{|l|}{ Treatment } \\
\hline Surgery & $59(46.8)$ & Reference & $1.274-3.599$ & $0.004^{\mathrm{a}}$ & Reference & $1.317-4.399$ & $0.004^{\mathrm{a}}$ \\
\hline CRT & $67(53.2)$ & 2.142 & & & 2.407 & & \\
\hline
\end{tabular}

CRT, chemoradiotherapy; OS, overall survival; c T, clinical Tumor; c N, clinical Node; Lt, lower thoracic; M/D, moderately differentiated; Mt, middle thoracic; P/D, poorly differentiated; RFS, recurrence-free survival; Ut, upper thoracic; W/D, well differentiated. ${ }^{a} \mathrm{P}<0.05$.

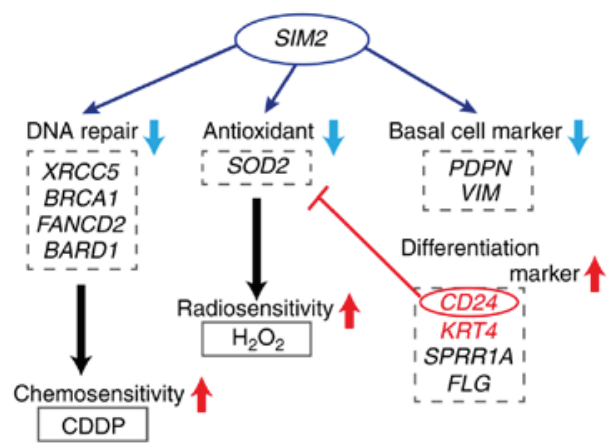

Figure 6. Schematic summary of the possible roles of SIM2 in definitive CRT for ESCC. CD24 may be involved in radiosensitivity through SOD2 suppression, but not chemosensitivity.

(EMT) (35). Furthermore, downregulation of CD24 has been reported to suppress bone metastasis of lung cancer cells (36). However, the role of CD24 in ESCC remains to be determined.

Our recent studies reported that transfection with SIM2 reduced the podoplanin (PDPN)-positive basal cell ratio and improved sensitivity to CDDP $(12,13)$. Knockdown of PDPN has been reported to reduce resistance to CDDP (37). In the present study, in response to CDDP, the number of viable CD24 siRNA-transfected cells was not significantly decreased compared with the control cells, suggesting that CD24 was not involved in chemosensitivity. SOD2 is known to efficiently catalyze the dismutation of reactive oxygen species (38), which are induced by irradiation. This study demonstrated that CD24 may suppress SOD2 expression and thus reduce resistance to $\mathrm{H}_{2} \mathrm{O}_{2}$. These data indicated that $\mathrm{CD} 24$ may be involved in radiosensitivity through SOD2 suppression, but not in chemosensitivity (Fig. 6).

Transforming growth factor (TGF)- $\beta$ is a major inducer of EMT during embryonic development, as well as the pathogenesis 
of fibrotic disorders and cancer progression (39-41). In ovarian cancer, CD24 and EMT regulators have been reported to be induced by TGF- $\beta$ (35). This study investigated whether TGF- $\beta$ stimulated the expression of EMT regulator genes (TWIST1, TWIST2 and SNAI2), mesenchymal cell marker genes (CDH2 and $V I M)$ and $C D 24$. As shown in Fig. S2, TGF- $\beta$ upregulated CDH2, VIM and SNAI2, but downregulated CD24, TWIST1 and TWIST2 in T.Tn cells, suggesting that CD24 was not involved in TGF- $\beta$-mediated EMT in ESCC.

In conclusion, the results of the present study may foster development of the predictive biomarkers CD24 and CK4 for selection of the best therapeutic modality, including definitive CRT, in ESCC. It was hypothesized that IHC of CD24 and CK4 may be useful for patient stratification; however, biopsy samples are often too small $(2 \times 2 \mathrm{~mm})$ to show a significant difference. For clinical use, the cut-off values should be determined by future extensive immunohistochemical analyses using several sections from multi-institutional cohorts.

\section{Acknowledgements}

The authors would like to thank Mr. Richard De Lapp for editorial comments.

\section{Funding}

This study was supported by the Japan Agency for Medical Research and Development (Practical Research for Innovative Cancer Control; grant no. 19ck0106296h0003), Grant-in-Aid for Scientific Research from the Japan Society for Promotion of Science (grant nos. 18H03330 and 19K22892), and the National Cancer Center Research and Development Fund (grant no. 29-A-2).

\section{Availability of data and materials}

The datasets used and/or analyzed during the current study are available from the corresponding author on reasonable request.

\section{Authors' contributions}

KT, HS and TY contributed to the study conception and design. RK, MK and HS performed the microarray data analyses. KT, SF, MT and TY performed and evaluated IHC. RK, KT, FC and HS performed the cell line experiments. KT, TK, HD, KM, MM and TY analyzed the patient data. KT, SF, RK, FC and HS drafted the manuscript. All authors have read and approved the final manuscript.

\section{Ethics approval and consent to participate}

Written informed consent was obtained from all participants in this study. All procedures were approved by the responsible committee on human experimentation at National Cancer Center East (approval no. 16-97), and were conducted in accordance with the Helsinki Declaration.

\section{Patient consent for publication}

Patients provided informed consent for publication.

\section{Competing interests}

The authors declare that they have no competing interests.

\section{References}

1. Jemal A, Bray F, Center MM, Ferlay J, Ward E and Forman D: Global cancer statistics. CA Cancer J Clin 61: 69-90, 2011.

2. Kato K, Muro K, Minashi K, Ohtsu A, Ishikura S, Boku N, Takiuchi H, Komatsu Y, Miyata Y and Fukuda H; Gastrointestinal Oncology Study Group of the Japan Clinical Oncology Group (JCOG): Phase II study of chemoradiotherapy with 5-fluorouracil and cisplatin for stage II-III esophageal squamous cell carcinoma: JCOG trial (JCOG 9906). Int J Radiat Oncol Biol Phys 81: 684-690, 2011.

3. Ando N, Kato H, Igaki H, Shinoda M, Ozawa S, Shimizu H, Nakamura T, Yabusaki H, Aoyama N, Kurita A, et al: A randomized trial comparing postoperative adjuvant chemotherapy with cisplatin and 5-fluorouracil versus preoperative chemotherapy for localized advanced squamous cell carcinoma of the thoracic esophagus (JCOG9907). Ann Surg Oncol 19: 68-74, 2012.

4. Tanaka Y, Aoyagi K, Minashi K, Komatsuzaki R, Komatsu M, Chiwaki F, Tamaoki M, Nishimura T, Takahashi N, Oda I, et al: Discovery of a good responder subtype of esophageal squamous cell carcinoma with cytotoxic T-lymphocyte signatures activated by chemoradiotherapy. PLoS One 10: e0143804, 2015.

5. Arthur JF and Fenner ML: The influence of histological grading on prognosis in carcinoma of the tongue (a computer analysis of 299 cases). Clin Radiol 17: 384-396, 1966.

6. Rowe DE, Carroll RJ and Day CL Jr: Prognostic factors for local recurrence, metastasis, and survival rates in squamous cell carcinoma of the skin, ear, and lip. Implications for treatment modality selection. J Am Acad Dermatol 26: 976-990, 1992.

7. Bersten DC, Sullivan AE, Peet DJ and Whitelaw ML: bHLH-PAS proteins in cancer. Nat Rev Cancer 13: 827-841, 2013.

8. Chen H, Chrast R, Rossier C, Gos A, Antonarakis SE, Kudoh J, Yamaki A, Shindoh N, Maeda H, Minoshima S, et al: Single-minded and Down syndrome? Nat Genet 10: 9-10, 1995.

9. Dahmane N, Charron G, Lopes C, Yaspo ML, Maunoury C, Decorte L, Sinet PM, Bloch B and Delabar JM: Down syndrome-critical region contains a gene homologous to Drosophila sim expressed during rat and human central nervous system development. Proc Natl Acad Sci USA 92: 9191-9195, 1995.

10. Swanson HI, Chan WK and Bradfield CA: DNA binding specificities and pairing rules of the Ah receptor, ARNT, and SIM proteins. J Biol Chem 270: 26292-26302, 1995.

11. DeYoung MP, Tress M and Narayanan R: Identification of Down's syndrome critical locus gene SIM2-s as a drug therapy target for solid tumors. Proc Natl Acad Sci USA 100: 4760-4765, 2003.

12. Nakamura K, Komatsu M, Chiwaki F, Takeda T, Kobayashi Y, Banno K, Aoki D, Yoshida T and Sasaki H: SIM2l attenuates resistance to hypoxia and tumor growth by transcriptional suppression of HIF1A in uterine cervical squamous cell carcinoma. Sci Rep 7: 14574, 2017.

13. Tamaoki M, Komatsuzaki R, Komatsu M, Minashi K, Aoyagi K, Nishimura T, Chiwaki F, Hiroki T, Daiko H, Morishita K, et al: Multiple roles of single-minded 2 in esophageal squamous cell carcinoma and its clinical implications. Cancer Sci 109: 1121-1134, 2018.

14. Kay R, Rosten PM and Humphries RK: CD24, a signal transducer modulating $\mathrm{B}$ cell activation responses, is a very short peptide with a glycosyl phosphatidylinositol membrane anchor. J Immunol 147: 1412-1416, 1991.

15. Deng J, Gao G, Wang L, Wang T, Yu J and Zhao Z: CD24 expression as a marker for predicting clinical outcome in human gliomas. J Biomed Biotechnol 2012: 517172, 2012.

16. Su N, Peng L, Xia B, Zhao Y, Xu A, Wang J, Wang X and Jiang B: Lyn is involved in CD24-induced ERK1/2 activation in colorectal cancer. Mol Cancer 11: 43, 2012.

17. Liu C, Zheng S, Shen H, Xu K, Chen J, Li H, Xu Y, Xu A, Chen B, Kaku H, et al: Clinical significance of CD24 as a predictor of bladder cancer recurrence. Oncol Lett 6: 96-100, 2013.

18. Tanaka T, Terai Y, Kogata Y, Ashihara K, Maeda K, Fujiwara S, Yoo S, Tanaka Y, Tsunetoh S, Sasaki H, et al: CD24 expression as a marker for predicting clinical outcome and invasive activity in uterine cervical cancer. Oncol Rep 34: 2282-2288, 2015. 
19. Baumann P,Cremers N, KroeseF, Orend G, Chiquet-Ehrismann R, Uede T, Yagita H and Sleeman JP: CD24 expression causes the acquisition of multiple cellular properties associated with tumor growth and metastasis. Cancer Res 65: 10783-10793, 2005.

20. Schabath H, Runz S, Joumaa S and Altevogt P: CD24 affects CXCR4 function in pre-B lymphocytes and breast carcinoma cells. J Cell Sci 119: 314-325, 2006.

21. Vazquez-Martin A, Oliveras-Ferraros C, Cufí S, Del Barco S, Martin-Castillo B, Lopez-Bonet E and Menendez JA: The anti-diabetic drug metformin suppresses the metastasis-associated protein CD24 in MDA-MB-468 triple-negative breast cancer cells. Oncol Rep 25: 135-140, 2011.

22. Takahashi M, Nakajima M, Ogata H, Domeki Y, Ohtsuka K, Ihara K, Kurayama E, Yamaguchi S, Sasaki K, Miyachi K and Kato H: CD24 expression is associated with progression of gastric cancer. Hepatogastroenterology 60: 653-658, 2013.

23. Overdevest JB, Thomas S, Kristiansen G, Hansel DE, Smith SC and Theodorescu D: CD24 offers a therapeutic target for control of bladder cancer metastasis based on a requirement for lung colonization. Cancer Res 71: 3802-3811, 2011.

24. Thomas S, Harding MA, Smith SC, Overdevest JB, Nitz MD, Frierson HF, Tomlins SA, Kristiansen G and Theodorescu D CD24 is an effector of HIF-1-driven primary tumor growth and metastasis. Cancer Res 72: 5600-5612, 2012.

25. Li C, Heidt DG, Dalerba P, Burant CF, Zhang L, Adsay V, Wicha M, Clarke MF and Simeone DM: Identification of pancreatic cancer stem cells. Cancer Res 67: 1030-1037, 2007.

26. Gao MQ, Choi YP, Kang S, Youn JH and Cho NH: CD24+ cells from hierarchically organized ovarian cancer are enriched in cancer stem cells. Oncogene 29: 2672-2680, 2010.

27. Sakamoto K, Aragaki T, Morita K, Kawachi H, Kayamori K, Nakanishi S, Omura K, Miki Y, Okada N, Katsube K, et al: Down-regulation of keratin 4 and keratin 13 expression in oral squamous cell carcinoma and epithelial dysplasia: A clue for histopathogenesis. Histopathology 58: 531-542, 2011.

28. Chung JY, Braunschweig T, Hu N, Roth M, Traicoff JL, Wang QH, Knezevic V, Taylor PR and Hewitt SM: A multiplex tissue immunoblotting assay for proteomic profiling: A pilot study of the normal to tumor transition of esophageal squamous cell carcinoma. Cancer Epidemiol Biomarkers Prev 15: 1403-1408, 2006.

29. Schaaij-Visser TB, Graveland AP, Gauci S, Braakhuis BJ, Buijze M, Heck AJ, Kuik DJ, Bloemena E, Leemans CR, Slijper M and Brakenhoff RH: Differential proteomics identifies protein biomarkers that predict local relapse of head and neck squamous cell carcinomas. Clin Cancer Res 15: 7666-7675, 2009.
30. Oken MM, Creech RH, Tormey DC, Horton J, Davis TE, McFadden ET and Carbone PP: Toxicity and response criteria of the eastern cooperative oncology group. Am J Clin Oncol 5: 649-655, 1982.

31. Sobin LH and Wittekind C (eds): TNM classification of malignant tumors. 6th edition. Wiley-Liss, New York, NY, 2002.

32. Livak KJ and Schmittgen TD: Analysis of relative gene expression data using real-time quantitative PCR and the 2(-Delta Delta C(T)) method. Methods 25: 402-408, 2001.

33. Ashida A, Boku N, Aoyagi K, Sato H, Tsubosa Y, Minashi K, Muto M, Ohtsu A, Ochiai A, Yoshida T, et al: Expression profiling of esophageal squamous cell carcinoma patients treated with definitive chemoradiotherapy: Clinical implications. Int J Oncol 28: 1345-1353, 2006.

34. Okabe H, Aoki K, Yogosawa S, Saito M, Marumo K and Yoshida K: Downregulation of CD24 suppresses bone metastasis of lung cancer. Cancer Sci 109: 112-120, 2018.

35. Nakamura K, Terai Y, Tanabe A, Ono YJ, Hayashi M, Maeda K, Fujiwara S, Ashihara K, Nakamura M, Tanaka Y, et al: CD24 expression is a marker for predicting clinical outcome and regulates the epithelial-mesenchymal transition in ovarian cancer via both the Akt and ERK pathways. Oncol Rep 37: 3189-3200, 2017.

36. Moon YW, An HJ, Koo JS, Kim GM, Han H, Park S, Kim SI, Park HS, Kim S, Kim SK, et al: CD44/CD24 and aldehyde dehydrogenase 1 in estrogen receptor-positive early breast cancer treated with tamoxifen: CD24 positivity is a poor prognosticator. Oncotarget 9: 2622-2630, 2017.

37. Rahadiani N, Ikeda J, Makino T, Tian T, Qiu Y, Mamat S, Wang Y, Doki Y, Aozasa K and Morii E: Tumorigenic role of podoplanin in esophageal squamous-cell carcinoma. Ann Surg Oncol 17: 1311-1323, 2010.

38. Zelko IN, Mariani TJ and Folz RJ: Superoxide dismutase multigene family: A comparison of the CuZn-SOD (SOD1), Mn-SOD (SOD2), and EC-SOD (SOD3) gene structures, evolution, and expression. Free Radic Biol Med 33: 337-349, 2002.

39. Taylor MA, Parvani JG and Schiemann WP: The pathophysiology of epithelial-mesenchymal transition induced by transforming growth factor-beta in normal and malignant mammary epithelial cells. J Mammary Gland Biol Neoplasia 15: 169-190, 2010.

40. Zavadil J and Böttinger EP: TGF-beta and epithelial-to-mesenchymal transitions. Oncogene 24: 5764-5774, 2005.

41. Lee YH, Albig AR, Regner M, Schiemann BJ and Schiemann WP: Fibulin-5 initiates epithelial-mesenchymal transition (EMT) and enhances EMT induced by TGF-beta in mammary epithelial cells via a MMP-dependent mechanism. Carcinogenesis 29: 2243-2251, 2008. 